Creative commons User License: CC BY-NC-ND

Abstracted by: EBSCOhost, Electronic Journals Service (EJS), Google Scholar, Directory of Open Access Journals (DOAJ), Journal Seek, Scientific Commons,

Food and Agricultural Organization (FAO), CABI and Scopus
Journal of Agricultural Extension

Vol. 21 (1) February, 2017

ISSN(e): 24086851; ISSN(Print); 1119944X

http://journal.aesonnigeria.org

http://www.ajol.info/index.php/jae

Email: editorinchief@aesonnigeria.org

\title{
Rural Household Attitude towards Traditional Methods of Malaria Treatment in South-East, Nigeria \\ http://dx.doi.org/10.4314/jae.v21i1.3
}

\section{Nwakwasi, R.N.}

Department of Agricultural Extension

Federal University of Technology, Owerri

Imo State. Nigeria

Email nwakwasiray@gmail.com; Phone: 08037742868

\section{Nwachukwu, I.}

Department of Rural Sociology and Extension

Michael Okpara University of Agriculture, Umudike Umuahia

Abia State. Nigeria

Email: nwachukwuike@ymail.com; Phone: +2348035485064

\section{Ifenkwe, G.E.}

Department of Rural Sociology and Extension

Michael Okpara University of Agriculture Umudike Umuahia,

Abia State. Nigeria

Email: ifenkwe.godwin@mouau.edu.ng: Phone: +2347062529000

\section{Agwu, E.A.}

Department of Agricultural Extension

University of Nigeria, Nsukka

Enugu State. Nigeria

Email: ekwe.agwu@unn.edu.ng; Phone: +2348034024251

\begin{abstract}
This study assessed rural households' attitude towards traditional methods of malaria treatment and cultural beliefs that affect choice of malaria treatment for enhanced agricultural production in south-east, Nigeria. A sample size of 360 household heads was randomly selected for the study. Data were collected with the use of structured questionnaire and Focus Group Discussions (FGD), key informant interview and participant observation. Descriptive statistics such as mean, frequency distribution and percentages were used to achieve the stated objectives.

Respondents from the three states studied had positive attitude towards traditional methods of malaria treatment (grand mean=3.47, 3.77, and 3.05 for Abia, Ebonyi and Imo States respectively), although respondents from Abia $(\bar{x}=2.83)$ and Imo States $(\bar{x}=2.41)$ disagreed that the environment under which traditional medicines for malaria treatment were prepared was hygienic. They indicated that traditional methods of malaria treatments have less chemical residues $(\bar{x}=3.50$ and 3.48 , for Abia, and Ebonyi States, respectively). The study suggests the need for collaborative efforts among all stakeholders, particularly orthodox medical personnel and traditional healers so as to have concerted efforts to ensure sustained malaria treatment.
\end{abstract}

Key words: Traditional treatment of malaria, Rural household's attitude to malaria treatment. 
Creative commons User License: CC BY-NC-ND

Abstracted by: EBSCOhost, Electronic Journals Service (EJS),

Google Scholar, Directory of Open Access Journals (DOAJ),

Journal Seek, Scientific Commons,

Food and Agricultural Organization (FAO), CABI and Scopus

\section{Introduction}

Malaria has been identified as a major obstacle towards achieving Millennium Development Goals 6 which is to ombat HIV and AIDS, malaria and other diseases. Malaria causes widespread premature death and suffering. It impacts on development of the country, reduces Nigeria's GNP by $1 \%$ annually ( $\$ 348$ million), and $25 \%$ of household income is expended on malaria control and treatment (Oladepo, et. al., 2010). It imposes financial hardship on poor rural households who have higher risk factors and greater malaria burden compared to urban dwellers considering the important role they play as major stakeholders in providing food for the nation. They often pursue diverse livelihood strategies that may comprise a number of different activities such as farming, herding, fishing, off-farm employment and the exploitation of natural resources through hunting and gathering (Nawrotzkiet. al., 2011).

Agriculture supports the health of rural households but poor health reduces farmers' ability to innovate, experiment and operationalize changes in agricultural systems, thus promoting poverty (Asenso-Okyere et. al., 2010). Agriculture provides income that can be spent on health care for farm families, making them resilient to health shocks. However, at the household level, malaria risk and disease burden is inequitably distributed because decisions for prevention or treatment are made depending on economic ability of the household (Onwujekwe, et. al., 2010).

Poverty has excluded a significant proportion of the population from accessing modern health care facilities among rural households, even when it is available. Poor access to proper treatment is also compounded by very low public expenditure on health, amounting to about USD14.00 per person per year (Mafimisebi and Oguntade, 2010). In Nigeria, the success of malaria control programmes relies heavily on community perception and practices related to the transmission, treatment and control of malaria. However, inappropriate beliefs and behaviours can interfere with the effectiveness of control measures. (Oladepo, et. al.,2010).

Rural households sometimes tend to blend traditional medicines with modern medicines. This is so because much of the world's biological diversity is in the 
Creative commons User License: CC BY-NC-ND

Abstracted by: EBSCOhost, Electronic Journals Service (EJS),

Google Scholar, Directory of Open Access Journals (DOAJ),

Journal Seek, Scientific Commons,

Food and Agricultural Organization (FAO), CABI and Scopus
Journal of Agricultural Extension

Vol. 21 (1) February, 2017

ISSN(e): 24086851; ISSN(Print); 1119944X

http://journal.aesonnigeria.org

http://www.ajol.info/index.php/jae

Email: editorinchief@aesonnigeria.org

custody of farmers who follow age-old farming and land use practices. These ecologically complex agricultural systems associated with centres of crop diversity include not only the traditional cultivars or 'landraces' that constitute an essential part of our world crop genetic heritage, but also wild plants and animal species that serve humanity as biological resources (Nwakwasi, 2013). Human behavior affects health promoting and disease preventing activities, increasing risk in some instances and in others reducing it (Amaechi and Ukpai, 2013).

Attitude toward malaria as a disease is important in understanding health-seeking behaviour and use of preventive methods. Many rural people do not trust Westernstyle medicine, preferring instead to use traditional ways which is an alternative or non-conventional mode of treatment involving the use of herbs in a non-orthodox manner, as well as the process of consulting herbalists, mediums, priests, witchdoctors, medicine men and various local deities (Mafimisebi and Oguntade, 2010). Good knowledge, attitude and practices of any public health disease by individuals and communities seems necessary if effective treatment and preventive measures are to be realistic (Iwueze et. al., 2013). These treatments are usually incorrect or sub-optimal since they are most times administered without proper diagnosis (Okeoluwapo et. al., 2008). Malaria is usually first treated at home with herbal teas and baths prepared with neem, pawpaw, guava, and eucalyptus leaves. Analysis of "what respondents will do first" during malaria attack showed that only 35.5 percent of respondents will use synthetic antimalarial drugs, 13.4 percent will use local herbs, while 27.3 percent will go to the hospital, and 18.2 percent will just pray (Asenso-Okyere et. al.,2009). Reliance on herbs as the first treatment action for malaria was also noted in South-east Nigeria upon which this paper intends to ascertain rural households' attitude towards traditional methods of malaria treatment and the perceived cultural beliefs that affect respondents' choice of malaria treatment and work towards ensuring the availability and potency of such drugs.

\section{Methodology}


Creative commons User License: CC BY-NC-ND

Abstracted by: EBSCOhost, Electronic Journals Service (EJS),

Google Scholar, Directory of Open Access Journals (DOAJ),

Journal Seek, Scientific Commons,

Food and Agricultural Organization (FAO), CABI and Scopus
Journal of Agricultural Extension

Vol. 21 (1) February, 2017

ISSN(e): 24086851; ISSN(Print); 1119944X

http://journal.aesonnigeria.org

http://www.ajol.info/index.php/jae

Email: editorinchief@aesonnigeria.org

This study was conducted in South-east Nigeria, situated east of River Niger and covering an area of 29,908 square kilometers, with a population of about $16,381,729$ persons. The region lies on latitude $5^{\circ}$ and $7^{\circ} 75^{\prime}$ north and longitude $6^{\circ}$ $85^{\prime}$ and $8^{\circ} 46^{\prime}$ east. It comprises five states namely: Imo, Enugu, Anambra, Ebonyi and Abia. The states in the zone share essentially similar characteristics (NPC, 2006). The zone covers the bulk of the Igbo-speaking ethnic territory. Major crops grown are yam, cassava, maize, cocoyam, melon, plantain, banana, garden egg, vegetables, and livestock (poultry, sheep, goat, and rabbit). There exist a variety of health-care types and services in Nigeria and south-east, which include traditional, bio-medical or western orthodox, synthetic healers, bone setters, etc however European Union rates South-East lowest in health care implementation (Eboh, 2007).

Multi-stage random sampling technique was employed for this study. First stage involved the random selection of three states out of the five states that make up south-east zone of Nigeria which are Imo, Abia and Ebonyi States. The second stage was the random selection of two agricultural zones from each of the selected states giving a total of six agricultural zones. The third stage of the sampling was the random selection of two Local Government Areas from each of the zones, giving a total of twelve Local Government Areas. The fourth stage was the random selection of three communities from each Local Government Area, giving a total of thirty-six communities. The fifth stage was the random selection of one village from each community selected and finally the simple random selection of ten household heads from each of the selected villages gave a sample size of 360 household heads for the study.

Quantitative primary data were collected through scheduled visits and interviews using structured questionnaire, Focus Group Discussions (FGD), key informant interview and participant observation. Copies of the questionnaire were administered on the randomly selected household heads. Where the husband and wife were present, they both decided who respond to the questions. Where one of the spouses was not present, the one present responded to the questions. 
Creative commons User License: CC BY-NC-ND

Abstracted by: EBSCOhost, Electronic Journals Service (EJS),

Google Scholar, Directory of Open Access Journals (DOAJ),

Journal Seek, Scientific Commons,

Food and Agricultural Organization (FAO), CABI and Scopus
Journal of Agricultural Extension

Vol. 21 (1) February, 2017

ISSN(e): 24086851; ISSN(Print); 1119944X

http://journal.aesonnigeria.org

http://www.ajol.info/index.php/jae

Email: editorinchief@aesonnigeria.org

Respondents' attitude towards traditional methods of malaria treatment was measured using a ten item scale eliciting information on attitude of respondents towards traditional methods of malaria treatment. Attitude was measured using a five-point Likert rating scale of strongly agree $=5$, agree $=4$, undecided $=3$, disagree $=2$ and strongly disagree $=1$. Based on the five-point scale, a mean score of 3.00 was obtained thus $5+4+3+2+1=15 \div 5=3.00$. Decision was taken thus: any mean response less than or equal to 3.00 suggests disagreement, while any mean response greater than 3.00 suggest agreement. To determine the index of attitude, the individual item scores were pooled together and a raw score obtained. Cultural beliefs of respondents that affect choice of methods of malaria treatment were measured using eight items eliciting information on cultural beliefs of respondents that affect choice of malaria treatment. This was measured using a five-point Likert rating scale of strongly agree $=5$, agree $=4$, undecided $=3$, disagree $=2$ and strongly disagree $=1$. Based on the five-point, a mean score of 3.00 was obtained thus $5+4+3+2+1=15 \div 5=3.00$. Decision was taken thus: any mean response less than or equal to 3.00 suggests disagreement, while any mean response greater than 3.00 suggest agreement. The objectives of this study were achieved using means, frequency distribution and percentages.

\section{Results and Discussion}

\section{Attitude of Farmers Towards Traditional Methods of Malaria Treatment}

Table 1 shows that households in Abia and Imo states accepted that the environment under which traditional malaria medicines were prepared was not hygienic with mean score of 2.83 for Abia, 2.41 for Imo State, while respondents in Ebonyi State were of the view that it was hygienic 
Creative commons User License: CC BY-NC-ND

Abstracted by: EBSCOhost, Electronic Journals Service (EJS),

Google Scholar, Directory of Open Access Journals (DOAJ),

Journal Seek, Scientific Commons,

Food and Agricultural Organization (FAO), CABI and Scopus
Journal of Agricultural Extension

Vol. 21 (1) February, 2017

ISSN(e): 24086851; ISSN(Print); 1119944X

http://journal.aesonnigeria.org

http://www.ajol.info/index.php/jae

Email: editorinchief@aesonnigeria.org

Table 1. Distribution of respondents according to their attitude towards traditional methods of malaria treatment

\begin{tabular}{|c|c|c|c|c|c|c|}
\hline \multirow[b]{2}{*}{ Indicator (Traditional) } & \multicolumn{2}{|l|}{ Abia } & \multicolumn{2}{|c|}{ Ebonyi } & \multicolumn{2}{|l|}{ Imo } \\
\hline & Mean & SD & Mean & SD & Mean & SD \\
\hline $\begin{array}{l}\text { The environment under which it is } \\
\text { prepared is very hygienic }\end{array}$ & 2.83 & 1.14 & *3.32 & 1.20 & 2.41 & 1.19 \\
\hline $\begin{array}{l}\text { It is easily accessible and is often } \\
\text { provided through more flexible } \\
\text { services. }\end{array}$ & *3.87 & 1.00 & *4.13 & 0.86 & *3.58 & 0.92 \\
\hline It is cheaper. & *3.88 & 1.04 & *4.43 & 0.73 & *3.42 & 1.27 \\
\hline Self-administered & *3.43 & 1.32 & *4.38 & 0.64 & *3.97 & 1.05 \\
\hline It has less chemical residue. & *3.50 & 1.11 & *3.48 & 1.00 & *3.01 & 1.03 \\
\hline It gives quicker relief & *3.38 & 1.17 & *3.35 & 1.20 & 2.99 & 1.12 \\
\hline $\begin{array}{l}\text { Methods of administration are not } \\
\text { dangerous (e.g. roots soaked in } \\
\text { alcohol and steam bath) }\end{array}$ & *3.06 & 1.27 & *3.28 & 1.12 & *3.18 & 1.22 \\
\hline & *3.45 & 1.09 & *3.56 & 0.68 & 2.53 & 1.28 \\
\hline & 2.36 & 1.03 & 2.28 & 1.04 & 2.19 & 1.09 \\
\hline It has expiry date & 2.56 & 1.20 & 2.53 & 1.19 & 2.37 & 1.25 \\
\hline Grand Mean & 3.47 & & *3.77 & & *3.05 & \\
\hline
\end{tabular}

Source: Field Survey data, 2015.

with a mean score of 3.32. Respondents in all the states accepted that some methods of administration of traditional malaria treatment was not dangerous to one's health with a mean score of 3.06 for Abia, 3.28 for Ebonyi and 3.18 for Imo State. The respondents in the three states all believed that traditional treatment was accessible and was often provided through more flexible services. Farmers will use much more of a particular commodity if they considered the quality good and if it was available when needed (Umar et.al., 2015) This further buttresses the fact that they preferred quick and natural methods of treatment that would readily serve their 
Creative commons User License: CC BY-NC-ND

Abstracted by: EBSCOhost, Electronic Journals Service (EJS),

Google Scholar, Directory of Open Access Journals (DOAJ),

Journal Seek, Scientific Commons,

Food and Agricultural Organization (FAO), CABI and Scopus
Journal of Agricultural Extension

Vol. 21 (1) February, 2017

ISSN(e): 24086851; ISSN(Print); 1119944X

http://journal.aesonnigeria.org

http://www.ajol.info/index.php/jae

Email: editorinchief@aesonnigeria.org

health needs for enhanced agricultural activities. This further gives credence to their assertion during the FGD that traditional treatment was cheaper, could be selfadministered and had less chemical residue. An overall mean value of 3.43 implies that farmers in South-East Nigeria had favourable attitude towards the use of traditional treatment for malaria. This is likely because of the usual flexible purchasing characteristics and the fact that they lack enough finance to take good care of themselves. This is in line with the findings of Shretta et.al. (2001) who said that traditional medicine providers are typically more flexible about payment arrangements, often permitting clients to pay in kind or by installment. This can be an important consideration when credit markets do not function well.

In all, the grand mean score of 3.77 of the response of the households in Ebonyi State was higher than the mean scores of 3.47 and 2.96 for Abia and Imo States, respectively, which showed that Ebonyi and Abia States had more positive attitude towards traditional method of malaria treatment. According to Giddens et al. (2005), people are dissatisfied with the way modern health care systems function, long waits, referrals through chains of specialists, financial restrictions, among other administrative challenges. Connected to this are concerns about the harmful side effects of medication and the intrusiveness of surgery-both techniques favored by modern health care systems. This can however be addressed by encouraging credible alternative means of treatment such as traditional medical services. When the ailments are complicated such as internal organs mal-functioning, mental illness or barrenness, the cost implications are far beyond the income capacity of the average citizen. In such instances, traditional method (TM) is the only option available for obtaining some remedy at affordable costs. Hence, a large proportion of Nigerians, especially those living in rural areas, continue to patronize TM. Convincingly, traditional medicine practitioners are responsive to the plight of their people and have concern for their welfare. Policy makers should therefore ensure that traditional medicine practitioners are involved in the planning and implementation of programmes geared towards improving the primary health care system in the country. However, community improvement on malaria intervention strategies appear particularly large in cases where communities actually make 
Creative commons User License: CC BY-NC-ND

Abstracted by: EBSCOhost, Electronic Journals Service (EJS),

Google Scholar, Directory of Open Access Journals (DOAJ),

Journal Seek, Scientific Commons,

Food and Agricultural Organization (FAO), CABI and Scopus
Journal of Agricultural Extension

Vol. 21 (1) February, 2017

ISSN(e): 24086851; ISSN(Print); 1119944X

http://journal.aesonnigeria.org

http://www.ajol.info/index.php/jae

Email: editorinchief@aesonnigeria.org

program decisions and where community program rollout is further delegated to local families and kinships (Amoran, 2013),

\section{Cultural Beliefs that Affect Choice of Malaria Treatments}

Table 2 reveals the cultural beliefs that affect households' choice of malaria treatment. Respondents in Ebonyi and Abia states believe that orthodox malaria treatment can cause deformity to the child in the womb if taken by pregnant women (with mean scores $=3.44$ and

3.14 respectively), while respondents from Imo did not see this as true. Households in Ebonyi and Abia states believed that traditional method of malaria treatment kept individuals safe from malaria for a longer time than Orthodox medicine with mean scores of 3.66 and 3.27, respectively. This is in line with the findings of Osemene et.al. (2011) who said that respondents believed that herbal or traditional treatments were safer and relatively more affordable than orthodox medicine. Respondents from Imo State had a dissimilar belief (mean score $=2.56$ ) that traditional malaria treatment when administered takes care of all illnesses in addition to malaria and also that a child with convulsion could die if given an injection, while respondents from Abia and Ebonyi states agreed. Only households in Ebonyi state believed that oily foods cause 
Creative commons User License: CC BY-NC-ND

Abstracted by: EBSCOhost, Electronic Journals Service (EJS),

Google Scholar, Directory of Open Access Journals (DOAJ),

Journal Seek, Scientific Commons,

Food and Agricultural Organization (FAO), CABI and Scopus
Journal of Agricultural Extension

Vol. 21 (1) February, 2017

ISSN(e): 24086851; ISSN(Print); 1119944X

http://journal.aesonnigeria.org

http://www.ajol.info/index.php/jae

Email: editorinchief@aesonnigeria.org

Table 2. Distribution of respondents according to cultural beliefs that affect choice of malaria treatments

\begin{tabular}{|c|c|c|c|c|c|c|}
\hline \multirow[b]{2}{*}{ Indicator } & \multicolumn{2}{|l|}{ Abia } & \multicolumn{2}{|c|}{ Ebonyi } & \multicolumn{2}{|l|}{ Imo } \\
\hline & Mean & SD & Mean & SD & Mean & SD \\
\hline $\begin{array}{l}\text { Orthodox treatment can cause } \\
\text { deformity to an unborn child }\end{array}$ & *3.44 & 1.19 & 3.14 & 1.21 & 2.35 & 1.15 \\
\hline $\begin{array}{l}\text { Traditional treatment keeps } \\
\text { individuals safe for a longer time }\end{array}$ & *3.27 & 1.18 & *3.66 & 1.31 & 2.99 & 1.21 \\
\hline $\begin{array}{l}\text { Traditional treatment takes care of } \\
\text { all illnesses. }\end{array}$ & *3.06 & 1.27 & 3.18 & 1.36 & 2.56 & 1.12 \\
\hline $\begin{array}{l}\text { A child with convulsion could die if } \\
\text { injected. }\end{array}$ & *3.64 & 1.16 & *3.35 & 1.20 & 2.41 & 1.19 \\
\hline Eating oily foods cause malaria & 2.85 & 1.29 & *3.33 & 1.22 & 2.83 & 1.10 \\
\hline Witch doctors treat malaria best & 1.92 & 1.06 & *3.45 & 1.09 & 2.53 & 1.28 \\
\hline Prayers cannot heal malaria & *3.20 & 1.56 & *3.23 & 1.42 & 2.95 & 1.47 \\
\hline $\begin{array}{l}\text { Orthodox } \\
\text { miscarriage }\end{array}$ & 2.94 & 1.35 & *3.38 & 1.16 & 2.99 & 1.21 \\
\hline Grand Mean & *3.04 & & *3.34 & & 2.71 & \\
\hline
\end{tabular}

Source: Field Survey data, 2015.

malaria, with a mean score of 3.33, while in Abia and Imo states, the households were not in support of this with mean score of 2.85 for Abia and 2.83 for Imo State. Respondents in Imo State accepted that prayers could heal malaria with mean score of 2.95 , as the saying goes, "the just shall live by faith". Only respondents in Ebonyi State believed that witch doctors treat malaria (mean score $=3.45$ ) and that orthodox medicine could cause instant miscarriage for pregnant women once taken (mean =3.38). An overall mean value of 3.03 showed that farmers in South-East Nigeria had strong ties to traditional methods of treatment because of their cultural beliefs against orthodox treatment. This result corroborates the assertion of Ekong 
Creative commons User License: CC BY-NC-ND

Abstracted by: EBSCOhost, Electronic Journals Service (EJS),

Google Scholar, Directory of Open Access Journals (DOAJ),

Journal Seek, Scientific Commons,

Food and Agricultural Organization (FAO), CABI and Scopus
Journal of Agricultural Extension

Vol. 21 (1) February, 2017

ISSN(e): 24086851; ISSN(Print); 1119944X

http://journal.aesonnigeria.org

http://www.ajol.info/index.php/jae

Email: editorinchief@aesonnigeria.org

(2010) that the influence of traditional medicine on the Nigerian society is still very strong.

It is a well-known fact that traditional knowledge forms an integral part of the culture and history of local communities and hence their common asset in their effort to gain control of their own lives. Indeed, rural communities apply - separately or in combination - plant, animal and mineral-based medicines, spiritual therapies, manual techniques and exercises to diagnose, prevent and treat illnesses, or maintain or enhance well-being. Awah, (2006) noted that in Africa, traditional medicine is a holistic concept which covers nature, the sociological environment whether living or dead, and the metaphysical forces of the universe. It therefore becomes important to build-in effective traditional treatment into the health care system for the benefit of our rural societies in Nigeria.

\section{Conclusion and Recommendation}

Generally, the respondents had positive attitude towards traditional methods of malaria treatment. They asserted that several orthodox methods of malaria treatment were dangerous and had several residual effects. Efforts should be made to encourage traditional and orthodox medical personnel to have collaborative research in malaria treatment. This can be done by working with traditional doctors in laboratories of teaching hospitals, pharmaceutical industries, NAFDAC, trade fares and seminars/ workshops. Traditional medicine practitioners should be encouraged to adopt best practices in the preparation, packaging and handling of traditional medicine, to encourage NAFDAC approval. This can be done through monitoring by sanitation officers and NAFDAC officials. Policies that will encourage this, as well as intensified trainings for traditional and even orthodox medicine producers and sellers should be put in place. The proper identification of genuine traditional medical practitioners by health care related task force is very important. 
Creative commons User License: CC BY-NC-ND

Abstracted by: EBSCOhost, Electronic Journals Service (EJS),

Google Scholar, Directory of Open Access Journals (DOAJ),

Journal Seek, Scientific Commons,

Food and Agricultural Organization (FAO), CABI and Scopus

\section{References}

Amaechi, E.C, \& Ukpai, O.M. (2013) Knowledge, attitude and practices about malaria among mothers and care-givers in Aba South Local Government Area, Abia State, Nigeria, AnimalResearch International, 10(3): 1784-1791.

Amoran, O.E. (2013). Impact of health education intervention on malaria: Prevention practices among nursing mothers in rural communities in Nigeria. Niger Med Journal, 54 (2): 115-122.

Asenso-Okyere, K. Asante, F. A., Tarekegn, J., \&Andam, K.S (2009). The Linkages between agriculture and malaria: Issues for policy, research, and capacity strengthening. Knowledge, Capacity, and Innovation Division. Washington, D.C.: International Food Policy Research Institute.

Asenso-Okyere, K., Kwaw A., Aragon, C., Thangata, P., \&Mekonnen, D. A. (2010). HIV and AIDS and farm labour productivity: A review of recent evidence in Africa.Journal of Development and Agricultural Economics, 2(12): 406-41.

Awah, P. (2006). Diabetes \&traditional medicine in Africa. Diabetes Voice, 51(3): 24-26.

Eboh, E. (2007). Economic and development profile of the South-East Zone. Memorandum for establishment of South-East Nigeria Economic Commission (SENEC). African Institute for Applied Economics, Enugu. Pp. 17-21. Rretrieved from http://www.aiaenigeria.org/senec/SENEC Memorandum.pdf.

Ekong, E. (2010). Rural Sociology: An introduction and Analysis of Rural Nigeria. (3rd ed.). Uyo, Nigeria: Dove Educational Publishers.

Giddens, A., Duneier, M. \& Appelbaum, R. (2005). Introduction to Sociology ( $5^{\text {th }}$ edition). 500 fifth Avenue, New York: W.W. Norton and Company Inc. Pp 106-108.

Iwueze, M. O., Ezugbo-Nwobi, I. K., Umeanaeto, P. U., Egbuche, C. M. \&Anaso, C. I. (2013). Knowledge, attitude and management practices on malaria: A case study of Amansea, Awka North Local Government Area of Anambra State, Nigeria. The Bio scientist, 1(1): 32-38.

Mafimisebi, T. E., \& Oguntade, A. E. (2010). Preparation and use of plant medicines for farmers' health in Southwest Nigeria: socio-cultural, magico-religious and economic aspects Journal of Ethno biology and Ethno medicine, 6 (1):1746-4269.

National Population Commission (2006). Population figure Federal Republic of Nigeria. http.www.npc.gov

Nawrotzki, R. J., Hunter, L. M. \&Dickinson, T.W. (2011). Rural livelihoods and access to natural capital: Differences between migrants and non-migrants in Madagascar. Demographic Research, 26(24): 661-700. 
Creative commons User License: CC BY-NC-ND

Abstracted by: EBSCOhost, Electronic Journals Service (EJS),

Google Scholar, Directory of Open Access Journals (DOAJ),

Journal Seek, Scientific Commons,

Food and Agricultural Organization (FAO), CABI and Scopus

\section{Journal of Agricultural Extension}

Vol. 21 (1) February, 2017

ISSN(e): 24086851; ISSN(Print); 1119944X

http://journal.aesonnigeria.org

http://www.ajol.info/index.php/jae

Email: editorinchief@aesonnigeria.org

Nwakwasi, R.N. (2013). Indigenous knowledge in extension services in Nigeria: In I. Nwachukwu (ed.). Agricultural extension and rural development: Promoting Indigenous Knowledge. Umuahia: Lamb House Publications: Pg. 163-173.

Okeoluwapo, O.A., Falade, C.O., Bamgboye, E.A., Oduala, A.M. \&Kale, O.O. (2008). Assessment of improvement guideline to improve home management of malaria in children in rural south-west Nigeria. Journal of BioMed Central, 7(24): 1475-1587

Oladepo, O., Tona, G.O., Oshiname, F.O., Musibau, A. \&Titiloye, M, A. (2010). Malaria knowledge and agricultural practices that promote mosquito breeding in two rural farming communities in Oyo State, Nigeria. Malaria Journal, 9(91): 1475-2875.

Onwujekwe, O. Obikeze E., Uzochukwu B., Okoronkwo I. \&Onwujekwe O. C. (2010). Improving quality of malaria treatment services: assessing inequities in consumers' perceptions and providers' behaviour in Nigeria. International Journal for Equity in Health, 9(22) doi:10.1186/1475-9276-9-22.

Osemene, K.P., Elujoba, A.A., \&llorin, M.O. (2011). A Comparative assessment of herbal and orthdox medicine in Nigeria. Research Journal of Medical Sciences, 5(5):280285.

Shretta, R., Gandaho, T. \& Malenga, G. (2001). How the Roll Back Malaria Partnership can promote universal access to effective anti malarial drugs: Examples of anti malarial drug policy and drug management systems from Malawi, Kenya, Cambodia and Senegal: A background paper for the Fourth RBM Global Partners Meeting 18-19 April 2001, Washington D.C.: Malaria Consortium.

Umar, S., Oteikwu, P.O., Shuaibu, H. Duniya, P.K. \& Tambari, I.W. (2015). Factors influencing level of satisfaction with growth enhancement support scheme among farm families in Kaduna State, Nigeria. Journal of Agricultural Extension, 19(1):5980 . 